\title{
Introduction: The Religious and the Secular
}

\author{
Everett Hamner
}

As an undergraduate at Johns Hopkins in the mid-nineties, I visited one of my advisors during office hours. As I accepted the proffered chair and my marked-up paper, she gave me a gentle but unambiguous message: "Everett, if you really want to go to graduate school in English, you've got to stop writing about religion. There's nowhere to do that anymore." In context, her advice was well-intended; Northrup Frye's examinations of biblical typology were ancient history. A decade later, however, with theorists as prominent as Jacques Derrida, Stanley Fish, and Slavoj Zizek openly confronting the "return of the religious," such counsel is more difficult to imagine. As Mary Louise Pratt asked in her 2003 Presidential Address to the Modern Language Association, "Who can doubt today the need to study secularism and religiosity from every viewpoint we can muster?" (427). This issue of The Iowa Journal of Cultural Studies pursues such viewpoints, recognizing that the religious and the secular are urgent categories for cultural study that show all the signs of an emergent discourse.

The articles in this journal issue question the religious and the sacred and seek to "muster" every viewpoint possible. The first three are primarily theoretical interventions, while the latter two mobilize theory through careful attention to specific cultural phenomena. In the first article, Christopher J. Roberts reexamines Marx's thinking on religion and emerges with what may be to many a startling discovery: when Marx refers to religion as "the opium of the masses," his tone is closer to empathy than to exposé. Reading Marx through Durkheim and Weber, he demonstrates that religion must be considered not only as part of society's superstructure, but also as part of the base - that in fact we must recognize "religion serving 
not only as a solace, but also as a catalyst." Ultimately, echoing Zizek's thoughts on how ideology is at its most powerful when it offers us freedom from ideology, Roberts concludes that "we are never more beset by a fixed, inflexible, and unconscious narrative than when we insist that we are finished with or beyond religion."

The next two articles are broader theorizations of the religious and the secular. Roland Boer is particularly interested in the shift he observes in his students from identifying themselves as "religious" to calling themselves "spiritual." Working with Bloch, Benjamin, Adorno, and others to connect religion with utopia and "the discernment of myth," he explains how secularization "never quite seemed to succeed" because its "rejection of Christianity relies on Christianity." Then, Carol Wayne White critiques the assumptions of both "theological" or confessional approaches and Enlightenment-driven, purportedly objective approaches to religious studies. In seeking an alternative that builds especially on the recent work of Russell McCutcheon, she acknowledges "the inevitable processes of open-ended textuality," but also stresses that "just as we should not participate in naïvely essentialist notions of selfhood, we must be careful not to construct an insufficient subjectivity, where historical agents are 'erased' by linguistic forces over which they can have little or no control."

The last two articles both suggest how attention to the religious and the secular can elucidate close readings of popular culture. Ruth Barcan and Jay Johnston provide a compelling argument for cultural study of alternative therapies, suggesting that this has not occurred because of the subject's link to questions of religion and spirituality; in fact, "religious and spiritual traditions furnish alternative healing practices with the core ontological characteristics that define the forms of subjectivity that are foundational to their specific healing practices." Employing a modified Foucauldian approach, they give particular attention to acupuncture and herbalism, linking the former to Taoism and the latter to the Western Esoteric Tradition. Likewise, Jean Lauer reads the recent Mexican films Santitos and The Crime of Padre Amaro as case studies of the way contemporary relationships between women and their priest-confessors continue to reflect the Catholic Inquisition's influence on colonial Mexico. Building on archival work on the nation's history, she asks how the two films' main characters upset mother and prostitute stereotypes. Even more compellingly, she considers why the films present the women in such a setting, "within the purview of the Church, but in defiance of 'the rules' established by the Church and by society."

I would also urge readers of the journal to take time to browse the issue's book reviews. Written by both established scholars of religion and culture and graduate students, they further investigate some of the texts surveyed in this introduction, as well as others not mentioned here. Lori Branch and I are grateful to all of those who submitted their work to this project, and hope that the outcome will prove stimulating for many others.

The significance of this project is that historically, whether consciously or unconsciously, the viewpoints sought for literary study have tended to treat the religious and the secular as absolutely separate categories. While it may seem convenient to bracket "church" from "state" or "the supernatural" from "the natu- 
ral," however, a binary approach unnecessarily restricts our inquiry in this arena as surely as it does in terms of race and gender. Instead, in the remainder of this essay, I review a wide range of significant texts for the development of this field, and I ask: What is generated by neglecting the religious, the secular, or both? Conversely, what would it look like to take both seriously?

In working through these questions, I consider approaches to religion from thinkers as diverse as Freud, Talal Asad, René Girard, Danièle Hervieu-Léger, Graham Ward, and Derrida. Gradually, I develop several key claims: (1) in modern and postmodern secularization, the religious is not absorbed by the secular, but reorganized through it, so that the secular may actually serve as evidence of the religious; (2) secularism is a modern (and postmodern) fundamentalist ideology that emerges from within religion, not outside it; (3) a central characteristic of the modern and postmodern religious is the paradoxical attempt to control the transcendent by immersing the self in virtual communion with the spectacular, whether the setting is the internet, the cinema, a theme park, or a megachurch; and (4) our religious-secular binary can only be fleshed out when we recognize how it erases both the distinction between and the interpenetration of faith and knowledge.

Danièle Hervieu-Léger's Religion as a Chain of Memory is a helpful place to turn for an initial definition of "religion." She suggests why the term is so notoriously difficult to delineate:

Functional [or inclusive] definitions can only testify to the dispersion - intellectually beyond control - of religious symbols in contemporary societies; while substantive [or exclusive] definitions can do no more than reiterate analysis of the loss of religion in the modern world. Both constitute a partial, yet radically limited, response to the question of the location of religion in modernity. Religion is nowhere, or else it is everywhere, which in the end comes to the same thing. (38)

These extremes can be avoided, however, by assuming that "there is no religion without the authority of a tradition being invoked (whether explicitly, half-explicitly or implicitly) in support of the act of believing" (76). With memory's centrality in mind, then, Hervieu-Léger offers a basic definition: "a religion is an ideological, practical and symbolic system through which consciousness, both individual and collective, of belonging to a particular chain of belief is constituted, maintained, developed and controlled" (82). This definition seems judicious, as long as one remembers that the "ideological, practical and symbolic system" may be "implicit," as Hervieu-Léger says, or even invisible and unconsciously assumed.

As my professor's decade-old guidance suggests, however, such a broad conception of religion has been uncommon in the academy. Like Marx's famous (and, as Christopher Roberts's article herein demonstrates, usually de-contextualized) reference to European, state-sponsored Christianity as the "opium of the masses," Freud's The Future of an Illusion typifies the attitude toward religion that dominated critical theory and practice in the twentieth century. Understandably, Freud asserts that "religious ideas have arisen from the same need as have all the other achievements of civilization: from the necessity of defending oneself against the crushingly superior force of nature [and] the urge to rectify the shortcomings of 
civilization which made themselves painfully felt" (26-27). While this assessment is sometimes accurate, Freud evinces a curious tension between an apparent desire to see all religion eliminated and his awareness that such an elimination cannot be forced. He assumes that:

all [religious doctrines] are illusions and insusceptible of proof. No one can be compelled to think them true, to believe in them. Some of them are so improbable, so incompatible with everything we have laboriously discovered about the reality of the world, that we may compare them - if we pay proper regard to the psychological difference - to delusions. Of the reality value of most of them we cannot judge; just as they cannot be proved, so they cannot be refuted. (40)

Surprisingly, as we will see, Freud sounds for a moment like Derrida some seventy years earlier: he acknowledges that belief is inherently different from knowledge, because it does not rely on the language of proof. Nonetheless, he insists that all religion is illusion, and decries it as the source of society's intellectual poverty. "Think of the depressing contrast between the radiant intelligence of a healthy child and the feeble intellectual powers of the average adult," he enjoins. "Can we be quite certain that it is not precisely religious education which bears a large share of the blame for this relative atrophy?" (60). Freud's central hope is that "a turning-away from religion is bound to occur with the fatal inevitability of a process of growth, and that we find ourselves at this very juncture in the middle of that phase of development" (55).

Freud's work suggests how the secular was perceived in the academy in the early twentieth-century. In this understanding, religion involves the institutionalization of claims about the divine or supernatural, while the secular sphere encompasses everything else - the natural and the ordinary. This assumption became commonplace for work in the tradition of Max Weber and Emile Durkheim, but today sociologists are questioning it in some measure. For instance, Pippa Norris and Ronald Inglehart's Sacred and Secular: Religion and Politics Worldwide, defends some versions of secularization, but offers the following caveat: "this does not imply that all forms of religion necessarily disappear as societies develop; residual and symbolic elements often remain, such as formal adherence to religious identities, even when their substantive meaning has faded away" (18). If it is unclear why the "symbolic" is not "substantive," the project's main conclusions deserve an even closer reading. Having attempted a global measurement of church attendance and "belief in God," Norris and Inglehart reveal "two apparently contradictory trends: (1.) The publics of virtually all advanced industrial societies have been moving toward more secular orientations during the past fifty years. Nevertheless, (2.) The world as a whole now has more people with traditional religious views than ever before - and they constitute a growing proportion of the world's population" (235). We are to understand that the text empirically demonstrates a "return of the religious" led by the subaltern (who may have never "left" it), which is intriguing in itself; however, what is more ironic is that Norris and Inglehart demonstrate this only through the assumption that a neat line can be drawn between sacred and secular phenomena. One must seriously question whether people appearing weekly 
in churches and telling surveyors that they believe in God makes a culture more "religious" than any other.

My reservations about a project in the social sciences by no means suggests that I view the humanities as immune from confusion about these terms. While there is much to admire about Leigh Eric Schmidt's Hearing Things: Religion, Illusion, and the American Enlightenment, for example, it implies that the secular eliminates the religious. We need to think twice when Schmidt overstates "the absorption of the sacred and the magical into diverting, didactic spectacles" (137) or "the sacred's strange disappearance under the cloak of entertainment" (161), or when he observes that "all the atmosphere of supernatural solemnity which enveloped the sorcerer and the cabalist of ancient times has dissolved away" (163). In conceptualizing modernity's and postmodernity's effects on the religious, metaphors like "absorption," "disappearance," and "dissolution" are far too absolute; Bronislaw Szersynski's term "reorganization" is more accurate. Hervieu-Léger urges that "instead of thinking of a dwindling religious domain (the institutions of traditional religion) set against the domains of politics, aesthetics, therapy and so on, one should look for covert signs of religion in every sphere of human activity" (29). While this can be taken too far, the point is that the secular does not eliminate the religious, but sifts and redistributes it.

Few theorists demonstrate the consequences of this distinction as powerfully as Talal Asad. In Formations of the Secular: Christianity, Islam, Modernity, he argues that "the categories of 'politics' and 'religion' turn out to implicate each other more profoundly than we thought [...]. The concept of the secular cannot do without the idea of religion" (200). Furthermore, he offers

a counter to the triumphalist history of the secular. I take the view, as others have done, that the "religious" and the "secular" are not essentially fixed categories. However, I do not claim that if one stripped appearances one would see that some apparently secular institutions were really religious. I assume, on the contrary, that there is nothing essentially religious, nor any universal essence that defines "sacred language" or "sacred experience." But I also assume that there were breaks between Christian and secular life in which words and practices were rearranged, and new discursive grammars replaced previous ones. (25, emphasis in original)

Asad, then, resists not only the common concept of secularization as religion's elimination, but also the fundamentalist denial that there exists an actual phenomenon that can be labeled "secularization." He uses the metaphor of "rearrangement," but with neither the overstatement of "replacement" found in Norris and Inglehart and Schmidt nor the understatement of "disguise" employed by extremists who would see religion everywhere in everything. With Asad, we arrive at the following conclusion: when the religious is acknowledged but not the secular, we have religious fundamentalism, and when the secular is acknowledged but not the religious, we have secularism - an absolutist ideology no less dangerous.

This is an apt place to meditate further on what we mean by "secularism." Asad's work investigates "a doctrine called secularism," which we must not mistake for 
dedication to plurality or diversity. "Secularism doesn't simply insist that religious practice and belief be confined to a space where they cannot threaten political stability or the liberties of 'free-thinking' citizens. Secularism builds on a particular conception of the world ('natural' and 'social') and of the problems generated by that world" (191-92). That conception of the world is "not simply an intellectual answer to a question about enduring social peace and toleration. It is an enactment by which a political medium (representation of citizenship) redefines and transcends particular and differentiating practices of the self that are articulated through class, gender, and religion" (5, emphasis in original). As an ideology, then, secularism denies the presence and significance of the religious, claiming to do so from an objective space outside of religion's influence. As we will see, the great irony here is that secularism is itself a product of religion.

While a number of theorists and historians recognize secularism's repression of the religious, René Girard's Deceit, Desire, and the Novel may be one of the most unexpected sources. Girard's central claims about mimetic desire are well known: in my own terms, rather than imagining that desire is only the interest of subject $X$ in object Y, we need to understand that it is X's adoration of mediator Z that leads her or him to co-opt Z's desire for Y. This desire can be either "external" or "internal": when there is sufficient distance between $\mathrm{X}$ and $\mathrm{Z}$, so that $\mathrm{Z}$ exists on a plane that is essentially unattainable or inaccessible for $\mathrm{X}$, this desire is external and less dangerous. As distance between $\mathrm{X}$ and $\mathrm{Z}$ decreases, however, the desire becomes internal and becomes a rivalry. As Girard explains, this is why hatred is so close to love: the adoration of $\mathrm{X}$ for $\mathrm{Z}$ causes his or her desire for $\mathrm{Y}$, but since $\mathrm{Z}$ also keeps $\mathrm{X}$ from $\mathrm{Y}, \mathrm{X}$ is led to hate $\mathrm{Z}$.

These are among the central claims of the oft-assigned early chapters of Girard's volume. However, the remainder of Girard's landmark text has received less attention, perhaps partly because we hesitate to raise issues of religion and secularism. Girard's later works are sometimes dismissed for addressing religion too extensively, but the seeds of the later claims are all here: for Girard, God is the ultimate mediator of Western culture, especially as expressed in Christ, and this is more true in a period characterized by secularism than ever before. In the early chapters, Girard shows that "the process of mediation creates a very vivid impression of autonomy and spontaneity precisely when we are no longer autonomous and spontaneous" (38); later, he applies this specifically to secularism. "Denial of God does not eliminate transcendency but diverts it from the au-delá [the beyond, the above, the afterlife] to the en-decá [the limited, the below, this life]. The imitation of Christ becomes the imitation of one's neighbor" (59). In other words, secularism is about replacing Christ as mediator of mimetic desire with more immediate cultural heroes, and then erasing all trace of the substitution. This has at least two effects: "Men [and women] boast of having discarded their old superstitions but they are gradually sinking into an underworld ruled by illusions which become increasingly obvious" (62), and "men [and women] of triangular desire no longer believe but are unable to get along without transcendency" (66). Girard does not deny that something crucial has changed with secularization, but he insists that humanity's present condition cannot be divorced from its past. Our present longings are in large mea- 
sure the product of religious beliefs that we cannot escape by adopting secularist repressions of that history.

Bronislaw Szersynski's Nature, Technology and the Sacred offers a similarly ambitious critique of secularism's blinders. Szersynski's 2005 book maps six manifestations of "the sacred," a term that he uses in order to suggest the mutual interpenetration of the religious and the secular. Szersynski's primal sacred, found today mostly among indigenous cultures, is an expression of polytheism in which gods inhabit the natural world, but remain numinous; the archaic sacred concentrates their power in specific objects, places, or persons that are closely tied to political power. The monotheistic sacred relocates the divine outside and above the now-empirical world, while the Protestant sacred further specifies (with the Reformation) that there can be no intermediaries between God and creation, thus making God both more sublime and more accessible privately than publicly. Out of these assumptions grows the modern sacred, in which life itself becomes the ultimate value, accessible via reason or emotion, and most recently the postmodern sacred, in which the very multiplicity of "sacreds" makes individual subjectivity into the new God. In each of these categories, Szerszynski's foundational claim is that the secular cannot exist independently of the sacred; "the religious meanings that frame the understanding of nature do not disappear over time - they just alter" (xi). In fact, "the illusion that the sacred has disappeared is arguably a feature of all historical transitions from one form of the sacred to the next in a given society" (26).

While Szersynski's structure is very helpful, it is worth questioning his preference for "the sacred" rather than "the religious." In English, the terms were once virtually synonymous: "religion" was first used to describe the holy calling of a monk or an order; the earliest medieval uses of "the sacred" also connote special purpose or dedication. In the wake of the Enlightenment, however, religion connotes participation in some system of belief, while the sacred becomes a looser antithesis to the secular. As a result, we no longer notice that our use of the term "the sacred" is itself a symptom of secularization, an effect of assuming the existence of an autonomous, empirical, objective reality which religion plays no part in shaping. In this sense, Szersynski's vocabulary conveys overtones of the ideology his text otherwise critiques so powerfully. Even with this reservation, however, Szersynski's main emphasis holds: what we have today is not "a secular wasteland, devoid of sacral meaning, but rather [...] a huge diversity of forms of enchantment" (171). Furthermore, the theorists whose concepts of secularization Szersynski approves (Max Weber, Robert Bellah, Jürgen Habermas, Marcel Gauchet) share a common claim: "rather than seeing secularization as something that impinges on the history of religion from outside, as the modernization of society undercuts the 'plausibility structures' of religion, this literature sees secularization as far more intimately related to that history - even to the point of seeing it as a phase within that history" (15).

I am especially interested in Szerszynski's claims about the modern and postmodern sacred. It seems to me that there is a paradox by which the modern and postmodern religious (my preferred terms) pursue control of the transcendent by immersing the self in virtual communion with the spectacular. Understanding this, however, depends on looking back to the monotheistic and Protestant religious as 
they develop in Europe and the Americas, and even to the primal and archaic religious. First, let us consider Max Weber's The Protestant Ethic and the Spirit of Capitalism, published a century ago now. Weber compellingly indicates how modern capitalism, rather than being the simple antithesis of Christian conceptions of value, was actually birthed by Protestant devotion to "intense worldly activity," which in reaction against Catholicism was regarded as the only way to "disperse religious doubts and give the certainty of grace" (112). As Weber shows, if "waste of time is thus the first and in principle the deadliest of sins" (157), then the calculating ethic of the industrial production line follows quite naturally. The move Weber traces is that from a broad monotheistic religious to one in which technological efficiency becomes the Holy Grail, or as Szersynski puts it, "the vertical transcendent axis is increasingly drawn into the empirical world. Instead of Being and order being seen as deriving from a supernatural source external to empirical reality, they are increasingly seen as properties of that reality itself' (20, emphasis in original). Weber shows, then, that the Protestant religious - and by extension the modern and postmodern religious - are heavily invested in the assumption that transcendence can and should be controlled by technology.

Still, the primal and archaic religious remain deeply relevant. Keith Thomas's Religion and the Decline of Magic, for example, suggests how the same instincts that drive modern and postmodern cultures to seek technological transcendence have also driven humanity toward the magical. This is one point where Freud's claim that religion is about protecting oneself from the unknowns of nature rings true: Thomas shows how conversion to Christianity has "frequently been assisted by the belief of converts that they are acquiring not just a means of other-worldly salvation, but a new and more powerful magic" (25). In turning from a profusion of numinous gods (primal religious) to their concentration in specific objects (archaic religious), and then to their further concentration in a single divinity (monotheistic religious), humanity seeks greater control of the divine. Not surprisingly, Thomas demonstrates that this causes moments of considerable confusion and blurring of distinctions: in medieval Christianity, "If any misfortune befell them or their animals their common saying was 'You have not crossed yourself well today', or 'You have not made the sign of the rood upon the cattle" (31). In other words, because it never wholly abandons the primal or archaic religious, the monotheistic religious can be understood as a matter of a new technique, or technology. For Thomas this is evident even in the Mass: "the clergy's anxiety that none of the consecrated elements should be wasted or accidentally dropped on the floor encouraged the idea that the Host was an object of supernatural potency." This led to the assumption that if the Host were secreted away in one's mouth, a person "could use it to cure the blind or the feverish; he could carry it around with him as a general protection against ill fortune, or he could beat it up into a powder and sprinkle it over his garden as a charm against caterpillars" (34). Despite the monotheistic trappings of Catholicism's triumph over pagan religions, then, Thomas indicates that the primal and archaic religious remain crucial sedimentary layers. He demonstrates that "the essential difference between the prayers of a churchman and the spells of a magician was that only the latter claimed to work automatically; a prayer had no cer- 
tainty of success and would not be granted if God chose not to concede it." However, even if the prayer was "supplication" and the spell was "a mechanical means of manipulation," "this distinction was repeatedly blurred in the popular mind" (41). When such obfuscation occurs, Thomas says, the resulting "advancement" to a new form of the religious can be understood as technological.

With Weber and Thomas in mind, we can better appreciate modernity and postmodernity's reinvestment in attempts to control the transcendent- to measure and prove it, to hold it down as object and use it. Here works by Graham Ward and Jacques Derrida become central: Ward's True Religion as explanation of the commodified religion that emerges in modernity and expands in postmodernity, and Derrida's Acts of Religion as confirmation of Ward as well as a vision of the "impossible" way forward. First, Ward claims that today "the only transcendence is experience of the spectacular itself" (29). He argues that "the end [of religion] does not signal the falling into disuse or the oblivion of the religious. Rather, it signals exactly the opposite: the extension and hype of the religious as the ultimate vision of the excessive and the transgressive" (34). In our times, religion is bound by technology to global capitalism (or what Derrida calls "globalatinization"), and our only goal is "to be consumed - for the subject to be ultimately and finally negated by becoming one with the Absolute" (76). This reflects precisely the strange concurrent desire to control and to be immersed within the transcendent; we buy and buy in order to possess tools that we ask to possess us. This "makes the ineffable not only effable but bearable" (114); instead of being unutterably other, the divine becomes a commodity fetish.

Above all, we turn to the spectacular. Ward's favorite example is the theme park, where we expect that the roller coasters will seem tremendously dangerous while remaining in reality entirely safe. We measure the experience "in terms of how close to experiencing raw violence one can come ... in safety. [...] Transcendence is equated with experiencing intensity or extremity" (121). However, we do not want to be truly fooled. One is mocked for genuine expressions of fear, so the arm-raised screams that come with a ninety-degree descent always hold onto a shred of irony, or at least so we claim later. "The simulations are to be enjoyed as simulations, the surface as surface" (123). We are not expected to "believe" in the special effect, the technological miracle, but simply to appreciate its technological genius. Indeed, I would suggest that this is why the "special features" of today's DVDs no longer hesitate to reveal how shots were accomplished: the secret itself is now a commodity, and the new effect alone justifies the price of admission, even if the film's other elements are banal.

Ward shows that rather than the secular eliminating the religious, the two categories constantly feed off and replenish each other. In postmodernity, "religion does not live in and of itself any more - it lives in commercial business, gothic and sci-fi fantasy, in health clubs, themed bars and architectural design, among happyhour drinkers, tattooists, ecologists and cyberpunks" (132-33). Those that consume such religion are not even buying religion; "they are consuming the illusions or simulations of religion" (133). This is entirely compatible with what Derrida says about how the modern and postmodern religious are inseparable from technoscience: "the imperturbable and interminable development of critical and technoscientific 
reason, far from opposing religion, bears, supports and supposes it. [...] religion and reason have the same source" (66). The real question is why we are so insistent in our attempts to hold them apart. This is the goal of secularism: to deny religion's importance, and as Zizek suggests, to mask the presence of ideology where it is most active, in secularism itself. "Why is this phenomenon, so hastily called the 'return of the religions,' so difficult to think? Why is it so surprising?" Derrida asks. "Why does it particularly astonish those who believed naïvely that an alternative opposed Religion, on the one side, and on the other, Reason, Enlightenment, Science, Criticism (Marxist Criticism, Nietzschean Genealogy, Freudian Psychoanalysis and their heritage), as though the one could not but put an end to the other?" (45, emphasis in original). Simply put, we have missed the way the modern religious employs both the rationalist logic and the technologies of the secularist ideology it claims to oppose, and conversely, how secularism stands or falls upon its opposition to religion.

Derrida's most thorough expansion on this claim is the sixty-page essay, "Faith and Knowledge: The Two Sources of 'Religion' at the Limits of Reason Alone," first published ten years ago and now found at the head of his volume Acts of Religion. This dense essay's central claim is that we must distinguish, on one hand, between "religion" that is bound with "a band of opposition" to Enlightenment objectivity, and on the other, a deeper, far less visible "faith." Certainly, he acknowledges that there is a modern religious that is nothing more than a mask for the rational, an "ontotheology which determines absolute knowledge as the truth of religion" (53). For Derrida, however, there is also a rarely explored abyss of faith yawning beneath the Enlightenment religion and science dancing around the volcano's rim. Between two apparently opposite ideologies - in reality committed to the same claims of certain knowledge Derrida imagines an aporia. Figuring it successively as the island, the Promised Land, and the desert, he identifies it as a place without certainty and without horizons of expectation, "where one neither can nor should see coming what ought or couldperhaps-be yet to come" (47). To make this central distinction, one must realize that "faith has not always been and will not always be identifiable with religion, nor, another point, with theology" (48). Where such identification can be made, Derridean faith resembles apophatic theology, or the via negativa, rather than the knowledgeenamored "proofs" of positivist theology. In any case, the key is to see that "the temptation of knowing, the temptation of knowledge, is to believe not only that one knows what one knows (which wouldn't be too serious), but also that one knows what knowledge is, that is, free, structurally, of belief or of faith-of the fiduciary or of trustworthiness" (68). With Derrida, then, we understand that if fundamentalism and secularism are opposing ideological attempts to repress either the religious or the secular, then faith and knowledge are opposed epistemologies by which we may, on one hand, take seriously both the religious and the secular, or on the other, acknowledge neither.

In order to understand how "knowledge" in Derrida's sense can be a product of neglecting both the religious and the secular, and how "faith" is found in the place of their convergence, consider another of his essays in Acts of Religion. "Force of Law: The "Mystical Foundation of Authority"" argues that "deconstruction takes place in 
the interval that separates the undeconstructibility of justice from the deconstructibility of law" (243). Without rehearsing the whole of that argument, it is enough to say that its distinction between the institutional law found in history and a more difficult to isolate, "impossible" justice is akin to that between knowledge-whether found in Enlightenment-based science or religion-and faith. In my terms, knowledge is a deconstructible, law-like institution that attempts to repress all discussion of either the religious or the secular, only implicitly recognizing that one invokes the other. On the other hand, faith, like justice, is not deconstructible because it exists at the heart of a dialectic, neither term of which it can deny. Rather than engaging technoscience in a battle to the death, as both fundamentalism and secularism understand religion to do, faith depends on giving place to both the religious and the secular.

One last essay in Derrida's volume, "The Eyes of Language: The Abyss and the Volcano," is especially helpful here. Confirming Zizek's idea that humanity's investment in belief is greater today than ever before, Derrida argues that this is evident simply because we use language. To do so is to take innumerable leaps of faith, however unconsciously: we act constantly on the hope that our interpreters will approximate the relationship between signifier and signified in a manner parallel to or at least compatible with our own understanding. When we deny this, pretending that language can be entirely objective, absolute, or empirical, we make insupportable claims of knowledge.

But we walk on the surface, we sleepwalk, only because we $b e$ lieve we are walking on the surface: we believe in the surface. In truth - and this truth no longer belongs to the order of objectivity or of knowledge that is conveyed by the secular language of the surface - there is no surface. There is only the abyss. Sacred language is an abyss. We walk as blind men on its surface when we speak about it. (202, emphasis in original)

Of course, this by no means indicates that faith is the simple, easy answer to our problem. Rather, "it is difficult to know whether what is more terrible is to walk on the surface as a blind man or to fall into the abyss as a man of lucid speech, awake, vigilant, awakened to the abyssal essence of language" (202-203). Like using language - though we often forget it - it is dangerous to recognize the depth of our faith, much less cultivate it.

I believe that we are aware of this faith at some level, but that it is only rarely identified as such in academic discussions of the religious and the secular. The story is usually told in one of two ways: fundamentalism has seen the university as recruiting ground, a place to demonstrate religion's rationalism, and secularism has put up an aggressive defense; alternatively, the university has defined "secular" to signify the exclusion of belief, and fundamentalism has fought for its very identity. The problem is that neither story offers hope of productive resolution, so humanities departments that are in fact the best positioned to engage these issues tend at best to shy away and at worst to engage in denial. Advice like that which I received from my advisor a decade ago remains possible, if less likely. Indeed, early in my doctoral work at the University of Iowa, I was again faced with considerable resistance from an instructor during office hours. "You know," this professor pondered, "it never ceases to amaze me that someone can be in grad school and still take 
religion seriously." Looking at me in honest bewilderment, he asked, "What the hell makes you think religion even matters any more?" In my mind, this experience suggests reason for both concern and hope: while I suspect that its profanity points toward an act of repression, not just a conviction of irrelevance, what stands out to me is that ten years ago I was offered a direct, absolute warning, but this scholar asked a question.

\section{Works Cited}

Asad, Talal. Formations of the Secular: Christianity, Islam, Modernity. Stanford: Stanford UP, 2003.

Derrida, Jacques. Acts of Religion. New York: Routledge, 2002.

Freud, Sigmund. The Future of an Illusion. 1927. Trans. James Strachey. New York: Norton, 1961.

Girard, René. Deceit, Desire, and the Novel: Self and Other in Literary Structure. 1961. Trans. Yvonne Freccero. Baltimore: Johns Hopkins UP, 1965.

Hervieu-Léger, Danièle. Religion as a Chain of Memory. Trans. Simon Lee. New Brunswick, New Jersey: Rutgers UP, 2001.

Marx, Karl. "Introduction." Contribution to the Critique of Hegel's Philosophy of Right. 1844. Ed. Scott Moore. Philosophy Dept., Baylor University. 9 March $2006<$ http://www3.baylor.edu/ Scott_Moore/texts/Marx_Contr_Crit.html>.

Norris, Pippa and Ronald Inglehart. Sacred and Secular: Religion and Politics Worldwide. Cambridge, England: Cambridge UP, 2004.

Pratt, Mary Louise. "Presidential Address 2003: Language, Liberties, Waves, and Webs - Engaging the Present.” PMLA 119.3 (May 2004): 417-28.

Schmidt, Leigh Eric. Hearing Things: Religion, Illusion, and the American Enlightenment. Cambridge, Massachusetts: Harvard UP, 2000.

Szerszynski, Bronislaw. Nature, Technology and the Sacred. Malden, Massachusetts: Blackwell, 2005.

Thomas, Keith. Religion and the Decline of Magic. New York: Charles Scribner's Sons, 1971.

Ward, Graham. True Religion. Oxford, England: Blackwell, 2003.

Weber, Max. The Protestant Ethic and the Spirit of Capitalism. 1905. New York: Dover, 2003. 